\begin{abstract}
HHS Public Access
Author manuscript

J Pathol. Author manuscript; available in PMC 2018 January 01.

Published in final edited form as:

J Pathol. 2017 January ; 241(2): 273-280. doi:10.1002/path.4833.

\section{The role of genetics in pulmonary arterial hypertension}

\author{
Lijiang $\mathrm{Ma}^{1}$ and Wendy K. Chung ${ }^{1,2}$ \\ ${ }^{1}$ Department of Pediatrics, Columbia University, New York, NY, USA \\ ${ }^{2}$ Department of Medicine, Columbia University, New York, NY, USA
}

\section{Abstract}

Group 1 pulmonary hypertension or pulmonary arterial hypertension $(\mathrm{PAH})$ is a rare disease characterized by proliferation and occlusion of small pulmonary arterioles, leading to progressive elevation of pulmonary artery pressure and pulmonary vascular resistance, and right ventricular failure. Historically it has been associated with a high mortality rate, although over the last decade, treatment has improved survival. PAH includes idiopathic PAH (IPAH), heritable PAH (HPAH), and PAH associated with certain medical conditions. The etiology of PAH is heterogeneous, and genetics play an important role in some cases. Mutations in BMPR2, encoding bone morphogenetic protein receptor type 2 , a member of the transforming growth factor beta (TGF- $\beta$ ) superfamily of receptors, have been identified in 70\% of cases of HPAH, as well as 10-40\% of cases of IPAH. Other genetic causes of PAH include mutations in activin receptor-like type 1 ( $A C V R L 1)$, endoglin ( $E N G)$, SMAD family member 9 (SMAD9), caveolin 1 (CAVI) and potassium two-pore-domain channel subfamily $\mathrm{K}$ member 3 (KCNK3). T-box 4 (TBX4) mutations have been identified in 10-30\% of pediatric PAH patients, but rarely in adults with PAH. PAH in children is much more heterogeneous than in adults and can be associated with several genetic syndromes, congenital heart disease, pulmonary disease, and vascular disease. In addition to rare mutations as a monogenic cause of HPAH, common variants in cerebellin 2 (CBLN2) increase the risk of PAH by approximately twofold. A PAH panel of genes is available for clinical testing and should be considered for use in clinical management, especially for patients with a family history of PAH.
\end{abstract}

\title{
Keywords
}

genetics; TGF $\beta$; BMPR2; CAV1; KCNK3; TBX4

\section{Introduction}

Based on the World Health Organization (WHO) clinical classification, pulmonary hypertension falls into five groups: pulmonary arterial hypertension (PAH) (Group 1);

Correspondence to: Wendy Chung, MD PhD, Columbia University, 1150 St. Nicholas Avenue, Room 620, New York, NY 10032, USA. Phone: 212-851-5313. Fax: 212-851-5306.wkc15@ columbia.edu.

Conflict of interest: The authors report no conflicts of interest in this work.

Author contribution statement

Both authors contributed to writing the manuscript and approved the final version. 
pulmonary hypertension due to left heart disease (Group 2); pulmonary hypertension due to chronic lung disease and/or hypoxia (Group 3); chronic thromboembolic pulmonary hypertension (Group 4); and pulmonary hypertension due to unclear multifactorial mechanisms (Group 5).

Pathologically, PAH is characterized by excessive pulmonary vasoconstriction, abnormal vascular remodeling (including medial hypertrophy, intimal fibrosis, and adventitial proliferation) and obliteration of small pulmonary arterioles, leading to progressive elevation of pulmonary artery pressure, which in turn increases afterload of the right ventricle [1) (Figure 1). In response to vascular stress, the effects of genetic risk factors, such as BMPR2 mutations, will interplay with those of other signaling molecules (kinases and growth factors). There is hypertrophy of smooth muscle cells, deposition of extracellular matrix, proliferation of endothelial cells, propagation of adventitial fibroblast cells and remodeling of small pulmonary arteries. Despite recent improvements in management, PAH remains a devastating disease. The pathogenesis of PAH is complex and incompletely understood, but includes both genetic and environmental factors that alter vascular structure and function [2]. Understanding the genetic etiology of PAH should facilitate better diagnosis and development of novel therapies in the future.

\section{Genetics of PAH}

Familial cases of PAH have been long recognized [3] and are usually inherited as autosomal dominant traits with incomplete penetrance; females are preferentially affected. HPAH accounts for about $6 \%$ of PAH [4]. BMPR2, encoded by the gene most commonly mutated in HPAH, is a member of the transforming growth factor-beta (TGF- $\beta$ ) receptor superfamily; this comprises a large series of cytokine growth factors that control a host of cellular functions, among them proliferation, migration, differentiation, apoptosis, and extracellular matrix secretion and deposition. Multiple studies have identified BMPR2 mutations in 70\% of HPAH and $~ 10-40 \%$ of IPAH cases [5-8]. To date, 390 different BMPR 2 mutations have been identified (www.hgmd.cf.ac.uk). These are all loss-of-function mutations, and include nonsense, missense, splicing and frameshift mutations, as well as deletions or rearrangements affecting one or more exons or the entire BMPR2 gene [9]. It is suggested that nonsense or frameshift mutations cause truncation of the protein and lead to nonsensemediated decay, while missense mutations cause retention of the mutant protein in the endoplasmic reticulum or plasma membrane [10]. BMPR 2 mutations occur in about $20 \%$ of adult idiopathic PAH cases (Table 1) [11-22]. Although there is some variability, the average penetrance of $B M P R 2$ mutations is only about $20 \%$, and a "second hit" is proposed to be a modulator of disease progression [23-24]. Using lymphocyte-derived human cell lines to examine $B M P R 2$ expression, unaffected mutation carriers were shown to have higher levels of wild-type $B M P R 2$ transcripts than affected patients [25], suggesting that the penetrance of the disease is regulated by the level of expression of the normal BMPR 2 allele. These authors also suggested that there is an estrogen receptor-alpha binding site at the BMPR2 promoter and that $B M P R 2$ expression is reduced in lymphocytes from female patients compared with male patients [26]. 
Additional genes related to TGF- $\beta$ superfamily receptor signaling have been identified as rare causes of PAH; these include activin receptor-like type 1 ( $A C V R L 1)$, endoglin $(E N G)$, SMAD family member 8 ( $S M A D 8$; also known as $S M A D 9)$ and SMAD family member 4 (SMAD4) [27-34] (Figure 2). The TGF- $\beta$ family is involved in regulation of multiple cellular functions and homeostasis, including proliferation, differentiation, apoptosis and endothelialmesenchymal transition (endo-MT) [35]. TGF- $\beta$ plays an important role in the respiratory system [36]. The TGF- $\beta /$ ACVRL1/ENG signaling pathway activates or phosphorylates Smad1/5/8 and Smad2/3 through receptors such as BMPR2, and induces growth factors such as fibroblast growth factor 2 (FGF2) and platelet-derived growth factor B (PDGFB) [37]. TGF- $\beta$ regulates the synthesis of platelet-derived growth factors through the non-canonical pathway (C-terminal Src kinase or MAP kinase) in endothelial cells, which can stimulate the growth of vascular smooth muscle cells [38].

\section{Hereditary hemorrhagic telangiectasia genes}

Hereditary hemorrhagic telangiectasia (HHT) is a rare autosomal dominantly inherited disease characterized by telangiectases and arteriovenous malformations (AVMs), including pulmonary AVMs, with variable clinical presentations due to different locations of the lesion. Mutations in $E N G$ or $A C V R L 1$ are identified in $80-85 \%$ of HHT patients, while $S M A D 4$ mutations are found in $1-2 \%$ of HHT $[39,40]$. SMAD4 is a "co-SMAD" that forms a complex with receptor-activated SMADs (SMAD2/3 or SMAD1/5/8).

Growth differentiation factor 2 ( $G D F 2$, previously known as bone morphogenetic protein 9, $B M P 9$ ) is a rare genetic cause for HHT [41]; one study identified three heterozygous missense mutations in $G D F 2 / B M P 9$ in 1.6\% (3/191) of HHT patients [42], but heterozygous mutations in $G D F 2 / B M P 9$ have not been reported in HHT-PAH or isolated PAH. Recently, though, a homozygous $G D F 2 / B M P 9$ nonsense mutation c.C76T; p.Gln26Ter was identified in a child with isolated PAH [43]. The parents were heterozygous for the mutation but were phenotypically normal. It is estimated that $30 \%$ of HHT patients have pulmonary arteriovenous malformations, and a small percent $(<1 \%)$ of HHT patients have PAH [44]. In this small proportion of patients with HHT-PAH, some have PAH that is clinically and histopathologically indistinguishable from other heritable forms of PAH, while others have PAH associated with pulmonary arteriovenous fistulas [45]. The underlying causative factor in these patients is, typically, mutations of $A C V R L 1$. Up to $20 \%$ (16/83) of all detected mutations in ACVRL1 are associated with the development of PAH, and, of these 16 mutations, $81 \%$ are repeatedly observed with PAH [46-47]. In rare instances (n=5), mutations of $A C V R L 1$ cause PAH without HHT [48-49].

\section{Caveolin 1}

Mutations in caveolin $1(C A V I)$ are a rare cause of HPAH and IPAH [50]. CAV1 encodes a membrane protein which is enriched in cell surface caveolae and plays an important role in mediating TGF- $\beta$, G-protein and nitric oxide signaling in PAH. $C A V 1$ is expressed ubiquitously, but with high expression in adipocytes, endothelial cells, and fibroblasts [51]. Homozygous or heterozygous $C A V 1$ mutations have been identified in lipodystrophy or partial lipodystrophy patients [52-53]. Recently, heterozygous $C A V 1$ mutations were reported in isolated PAH or PAH associated with lipodystrophy [51, 54-55]. Mechanisms of 
CAV1 mutation in PAH have been extensively studied. In mouse, Cav1 is expressed in epithelial and endothelial cells of the septum which is located between the alveolar space and the blood capillaries in the lung [56]. In humans, $C A V 1$ was detected in the endothelium of pulmonary arteries [50]. BMPR2 localizes to caveoli and directly interacts with CAV1 in various cell types, including vascular smooth muscle cells [57-58]. Other studies suggest that BMPR2 signaling through SRC regulates CAV1 trafficking in PAH [59] (Figure 2).

\section{PAH due to $K C N K 3$ Mutations}

Potassium two-pore-domain channel, subfamily $\mathrm{K}$ member 3 (KCNK3), also known as $T A S K-1$, encodes an outwardly rectifying potassium channel that is sensitive to changes in extracellular $\mathrm{pH}$. Genetic and electrophysiological studies suggest that $K C N K 3$ mutation is a rare genetic cause of PAH [60]. $\mathrm{K}^{+}$channels are the largest and most diverse family of ion channels. According to their structure and composition, $\mathrm{K}^{+}$channels are classified into three main groups: voltage gated (6 transmembrane domains or 6TM), inward rectifiers (2TM) and two-pore-domain (4TM) channels [61-62]. Two-pore-domain channels $\left(\mathrm{K}_{2 \mathrm{P}}\right)$ are the most recently discovered family of potassium channels. KCNK3, also called TASK-1 or $\mathrm{K}_{(2 \mathrm{P})} 3.1$, belongs to this family of $\mathrm{K}^{+}$channels, characterized by 4 transmembrane domains and 2 pore domains per subunit. Abundant expression of $K c n k 3$ is described in rat, rabbit and human pulmonary artery smooth muscle cells. The function of this channel is to conduct leak $\mathrm{K}^{+}$current, maintain the resting membrane potential and regulate vascular tone of the pulmonary artery. Activation of the $\mathrm{K}^{+}$channel causes $\mathrm{K}^{+}$efflux, membrane hyperpolarization and vasodilatation [63-66]. Besides $K C N K 3$, single nucleotide polymorphisms in potassium voltage-gated channel subfamily A member 5 (KCNA5), another gene in the potassium channel family, have been reported in PAH patients. It is suggested that $K C N A 5$ is a genetic risk factor for the disease and KCNA5 has roles in determining pulmonary vascular tone, oxygen sensing, cell proliferation, and apoptosis [67-68].

\section{Pediatric PAH}

The prevalence of PAH in children is estimated to be $\sim 2.2$ cases per million, an order of magnitude lower than the estimated prevalence of 15-50 cases per million in adults [69]. Pediatric PAH includes IPAH, HPAH and PAH associated with congenital heart disease and with abnormal lung development.

The genetics of PAH in children has not been extensively studied, but the data suggest that PAH in children may have a different genetic etiology from that in adults. The pediatric studies have been limited in sample size, and additional larger studies need to be performed. One study identified no $B M P R 2$ mutations in 13 children with IPAH [70]. In a cohort of 57 pediatric PAH patients, $18 B M P R 2$ and $7 A C V R L 1$ mutation carriers were identified [71]. A study of PH associated with congenital heart disease (CHD) demonstrated that $22 \%$ of children had ACVRL1, ENG or BMPR2 mutations [8]. In a mixed cohort of 40 childhood PAH cases, including 29 IPAH/HPAH and 11 PAH-CHD, six BMPR2, two ACVRL1 and two $E N G$ mutations were identified [72]. The differences in genetic results in different pediatric PAH studies are probably due to a combination of small sample sizes, different genetic backgrounds and selection criteria, including whether the PAH was associated with 
other diseases. BMPR2 mutation-positive children appeared less likely to respond to acute vasodilators than mutation-negative children [17].

TBX4 is a transcription factor in the T-box gene family, expressed in the atrium of the heart, the limbs, and the mesenchyme of the lung and trachea. Jointly with TBX5, TBX4 has been shown to interact with FGF10 during lung growth and branching [73]. Heterozygous loss of function mutations in $T B X 4$ have been previously reported to cause small patella syndrome (SPS; MIM\# 147891) [74], and heterozygous microdeletions of 17q23.2 encompassing $T B X 4$ were identified in eight patients with developmental delay, limb abnormalities, CHD, and one with pulmonary hypertension [75-76]. One missense and two frameshift variants in $T B X 4$ were identified in 6/20 (30\%) pediatric PAH patients [21], and two missense variants in $T B X 4$ were identified in 2/49 adult PAH patients (4.1\%), suggesting a higher frequency of $T B X 4$ mutations in pediatric PAH. Although it had not initially been clinically noted, some of the patients and the asymptomatic parents carrying $T B X 4$ mutations were later assessed for skeletal signs of small patella syndrome (SPS); in all five available probands and two carrier parents there was radiological evidence of skeletal malformations [21]. In a cohort of 165 adult-onset PAH, only one possible mutation (non-frameshift insertion c. 310_312 ins AAG, p.L103_V104 ins E) in TBX4 was identified [22]. Rarely, TBX4 mutations have been associated with abnormal lung development, such as acinar dysplasia of the lungs [77]. Table 2 provides a summary of pediatric PAH genetic studies [16-17, 21, 70-72, 78-80].

Other genes are likely to play an important role in childhood PAH. Two novel missense mutations in BMPR1B were identified in pediatric IPAH [81]. These two variants are located in highly conserved BMPR1B protein regions. Functional studies showed that BMPR1B mutant protein increased phosphorylation of SMAD8. BMPR1B (also known as ALK6) is one of the BMP type I receptors which interact with BMP type II receptors and mediates BMP signaling. BMPR1B expression was significantly increased in pulmonary artery smooth muscle cells (PASMC) isolated from BMPR2-negative PAH patients, while BMPR1B transcripts were hardly detectable in control PASMC [82].

Two novel missense mutations (G840E and T900P) in NOTCH3 were identified in two PAH patients. These variants are located in highly conserved NOTCH3 protein regions. Functional studies indicated that these mutations increased cell proliferation and viability [83], suggesting a possible gain of function. As the receptor for JAGGED1, NOTCH3 is involved in vascular homeostasis and $\mathrm{PAH}$ [84]. Evidence suggests that TGF- $\beta 1$ regulates Notch3, indicating that Notch3 is in the TGF- $\beta$ signaling network [86].

\section{Genetics and environmental factors interact in PAH}

The genetics of PAH across multiple genes are characterized by female predominance and incomplete penetrance of dominantly inherited mutations. The age of onset can be modified by a complex interplay of multiple mutations. One BMPR 2 mutation carrier has been shown to have a loss of Chromosome 13 in the pulmonary vasculature, associated with loss of $S M A D 9$ [23]. Some patients have been found to carry multiple variants in PAH risk genes [86]. Differences in $B M P R 2$ expression or isoform ratios may provide an explanation for the reduced penetrance among BMPR2 mutation carriers [87]. The onset of PAH can be 
modified by association with other diseases or exposures. Heterozygous $B M P R 2$ sequence variants have been identified in a small subset of patients with PAH associated with exposure to fenfluramine [13, 88], CHD [16], and veno-occlusive disease [89-90], raising the possibility that these factors represent triggers in the setting of inherited susceptibility. In contrast, $B M P R 2$ mutations have not been identified in modestly sized series of PAH associated with the scleroderma-spectrum disease, human immunodeficiency virus [91-92], Down syndrome [93], neurofibromatosis 1 [94], Gaucher disease [95] or autoimmune polyendocrine syndrome [96]. Additionally, the onset of disease can be modified by age [97], sex [26], epigenetic modifications [98], lifestyle [99] and environmental factors [100].

HPAH and IPAH generally have similar clinical courses, although there are some subtle but important differences. BMPR2 mutation carriers are younger at diagnosis and have worse hemodynamic parameters [17]. Both children and adults with PAH and BMPR2 mutations are less likely to respond to vasodilators and are unlikely to benefit from treatment with calcium channel blockade [17, 101]. Symptomatic HPAH patients carrying ACVRL1 mutations, most without HHT, have an earlier age of onset and more rapid disease progression than HPAH patients with $B M P R 2$ mutations, despite responsiveness to vasodilators at the time of diagnosis [102]. In contrast, many (but not all) $T B X 4$-related cases of PAH follow a more benign course compared with BMPR2 mutation carriers [22].

\section{Commons Variants Increase the Risk of PAH}

The cause of most IPAH is currently unknown, but common variants have been hypothesized to contribute to disease risk. A large international genome-wide association study (GWAS) identified common variants in cerebellin 2 (CBLN2) that were associated with HPAH and IPAH [103].

\section{Genetic Testing for PAH}

Clinical genetic testing is now available for $B M P R 2$ or for panels of PAH-associated genes, including BMPR2, ACVRL1, ENG, SMAD4, SMAD9, CAV1, KCNA5, KCNK3, GDF2 (BMP9) and NOTCH3. Genetic testing is appropriate for patients with HPAH, IPAH, and pediatric PAH, and is largely used to stratify risk for relatives of PAH patients. Genetic testing can be done by targeted sequencing together with some form of gene dosage analysis such as MLPA (multiplex ligation-dependent probe amplification). Genetic counseling should be offered for predictive testing to review the complexities associated with genes with moderate penetrance and without currently available prevention [104]. For at-risk family members, patient education to ensure awareness of disease symptoms and disease surveillance by echocardiogram every 3 years should enable early diagnosis and treatment which may improve outcomes.

\section{Conclusion}

The genetics of pulmonary hypertension are complex due to the genetic heterogeneity, incomplete penetrance and sexual dimorphism in adults. There are likely to be additional genes as well as genetic and environmental modifiers for PAH still to be identified. Furthermore, the genes involved may differ between children and adults with PAH. Larger 
genetic studies, including epidemiological data and hormonal levels will be necessary to tease apart these complexities.

\section{Acknowledgements}

This work was supported by a grant from the National Institutes of Health (R01 HL060056).

\section{References}

1. Tuder RM, Marecki JC, Richter A, et al. Pathology of pulmonary hypertension. Clin Chest Med. 2007; 28:23-42. [PubMed: 17338926]

2. Humbert M, Sitbon O, Chaouat A, et al. Survival in patients with idiopathic, familial, and anorexigen-associated pulmonary arterial hypertension in the modern management era. Circulation. 2010; 122:156-163. [PubMed: 20585011]

3. Dresdale DT, Michtom RJ, Schultz M. Recent studies in primary pulmonary hypertension, including pharmacodynamic observations on pulmonary vascular resistance. Bull N Y Acad Med. 1954; 30:195-207. [PubMed: 13141055]

4. Lane KB, Machado RD, Pauciulo MW, et al. Heterozygous germline mutations in BMPR2, encoding a TGF-beta receptor, cause familial primary pulmonary hypertension. The International PPH Consortium. Nat Genet. 2000; 26:81-84. [PubMed: 10973254]

5. Aldred MA, Vijayakrishnan J, James V, et al. BMPR2 gene rearrangements account for a significant proportion of mutations in familial and idiopathic pulmonary arterial hypertension. Hum Mutat. 2006; 27:212-213.

6. Cogan JD, Vnencak-Jones CL, Phillips JA 3rd, et al. Gross BMPR2 gene rearrangements constitute a new cause for primary pulmonary hypertension. Genet Med. 2005; 7:169-174. [PubMed: 15775752]

7. Cogan JD, Pauciulo MW, Batchman AP, et al. High frequency of BMPR2 exonic deletions/ duplications in familial pulmonary arterial hypertension. Am J Respir Crit Care Med. 2006; 174:590-598. [PubMed: 16728714]

8. Thomson JR, Machado RD, Pauciulo MW, et al. Sporadic primary pulmonary hypertension is associated with germline mutations of the gene encoding BMPR-II, a receptor member of the TGFbeta family. J Med Genet. 2000; 37:741-745. [PubMed: 11015450]

9. Ma L, Chung WK. The genetic basis of pulmonary arterial hypertension. Hum Genet. 2014; 133:471-479. [PubMed: 24442418]

10. Frump AL, Lowery JW, Hamid R, et al. Abnormal trafficking of endogenously expressed BMPR2 mutant allelic products in patients with heritable pulmonary arterial hypertension. PLoS One. 2013; 8:e80319. [PubMed: 24224048]

11. Deng Z, Morse JH, Slager SL, et al. Familial primary pulmonary hypertension (gene PPH1) is caused by mutations in the bone morphogenetic protein receptor-II gene. Am J Hum Genet. 2000; 67:737-744. [PubMed: 10903931]

12. Sztrymf B, Coulet F, Girerd B, et al. Clinical outcomes of pulmonary arterial hypertension in carriers of BMPR2 mutation. Am J Respir Crit Care Med. 2008; 177:1377-1383. [PubMed: 18356561]

13. Humbert M, Deng Z, Simonneau G, et al. BMPR2 germline mutations in pulmonary hypertension associated with fenfluramine derivatives. Eur Respir J. 2002; 20:518-523. [PubMed: 12358323]

14. Morisaki H, Nakanishi N, Kyotani S, et al. BMPR2 mutations found in Japanese patients with familial and sporadic primary pulmonary hypertension. Hum Mutat. 2004; 23:632.

15. Koehler R, Grünig E, Pauciulo MW, et al. Low frequency of BMPR2 mutations in a German cohort of patients with sporadic idiopathic pulmonary arterial hypertension. J Med Genet. 2004; 41:e127. [PubMed: 15591269]

16. Roberts KE, McElroy JJ, Wong WP, et al. BMPR2 mutations in pulmonary arterial hypertension with congenital heart disease. Eur Respir J. 2004; 24:371-374. [PubMed: 15358693] 
17. Rosenzweig EB, Morse JH, Knowles JA, et al. Clinical implications of determining BMPR2 mutation status in a large cohort of children and adults with pulmonary arterial hypertension. $\mathrm{J}$ Heart Lung Transplant. 2008; 27:668-674. [PubMed: 18503968]

18. Wang H, Cui QQ, Sun K, et al. Identities and frequencies of BMPR2 mutations in Chinese patients with idiopathic pulmonary arterial hypertension. Clin Genet. 2010; 77:189-192. [PubMed: 20002458]

19. Pfarr N, Szamalek-Hoegel J, Fischer C, et al. Hemodynamic and clinical onset in patients with hereditary pulmonary arterial hypertension and BMPR2 mutations. Respir Res. 2011; 12:99. [PubMed: 21801371]

20. Kabata H, Satoh T, Kataoka M, et al. Bone morphogenetic protein receptor type 2 mutations, clinical phenotypes and outcomes of Japanese patients with sporadic or familial pulmonary hypertension. Respirology. 2013; 18:1076-1082. [PubMed: 23675998]

21. Kerstjens-Frederikse WS, Bongers EM, Roofthooft MT, et al. TBX4 mutations (small patella syndrome) are associated with childhood-onset pulmonary arterial hypertension. J Med Genet. 2013; 50:500-506. [PubMed: 23592887]

22. Navas P, Tenorio J, Quezada CA, et al. Molecular Analysis of BMPR2, TBX4, and KCNK3 and Genotype-Phenotype Correlations in Spanish Patients and Families With Idiopathic and Hereditary Pulmonary Arterial Hypertension. Rev Esp Cardiol (Engl Ed). Jul 21.2016

23. Aldred MA, Comhair SA, Varella-Garcia M, et al. Somatic chromosome abnormalities in the lungs of patients with pulmonary arterial hypertension. Am J Respir Crit Care Med. 2010; 182:11531160. [PubMed: 20581168]

24. Machado RD, James V, Southwood M, et al. Investigation of second genetic hits at the BMPR2 locus as a modulator of disease progression in familial pulmonary arterial hypertension. Circulation. 2005; 111:607-613. [PubMed: 15699281]

25. Hamid R, Cogan JD, Hedges LK, et al. Penetrance of pulmonary arterial hypertension is modulated by the expression of normal BMPR2 allele. Hum Mutat. 2009; 30:649-654. [PubMed: 19206171]

26. Austin ED, Hamid R, Hemnes AR, et al. BMPR2 expression is suppressed by signaling through the estrogen receptor. Biol Sex Differ. 2012; 3:6. [PubMed: 22348410]

27. Johnson DW, Berg JN, Baldwin MA, et al. Mutations in the activin receptor-like kinase 1 gene in hereditary haemorrhagic telangiectasia type 2. Nat Genet. 1996; 13:189-195. [PubMed: 8640225]

28. McAllister KA, Grogg KM, Johnson DW, et al. Endoglin, a TGF-beta binding protein of endothelial cells, is the gene for hereditary haemorrhagic telangiectasia type 1. Nat Genet. 1994; 8:345-351. [PubMed: 7894484]

29. Shi Y, Massague J. Mechanisms of TGF-beta signaling from cell membrane to the nucleus. Cell. 2003; 113:685-700. [PubMed: 12809600]

30. Fernandez LA, Sanz-Rodriguez F, Blanco FJ, et al. Hereditary hemorrhagic telangiectasia, a vascular dysplasia affecting the TGF-beta signaling pathway. Clin Med Res. 2006; 4:66-78. [PubMed: 16595794]

31. Shintani M, Yagi H, Nakayama T, et al. A new nonsense mutation of SMAD8 associated with pulmonary arterial hypertension. J Med Genet. 2009; 46:331-337. [PubMed: 19211612]

32. Nasim MT, Ogo T, Ahmed M, et al. Molecular genetic characterization of SMAD signaling molecules in pulmonary arterial hypertension. Hum Mutat. 2011; 32:1385-1389. [PubMed: 21898662]

33. Drake KM, Zygmunt D, Mavrakis L, et al. Altered MicroRNA processing in heritable pulmonary arterial hypertension: an important role for Smad-8. Am J Respir Crit Care Med. 2011; 184:1400 1408. [PubMed: 21920918]

34. Nasim MT, Ogo T, Ahmed M, et al. Molecular genetic characterization of SMAD signaling molecules in pulmonary arterial hypertension. Hum Mutat. 2011; 32:1385-1389. [PubMed: 21898662]

35. Good RB, Gilbane AJ, Trinder SL, et al. Endothelial to Mesenchymal Transition Contributes to Endothelial Dysfunction in Pulmonary Arterial Hypertension. Am J Pathol. 2015; 185:1850-1858. [PubMed: 25956031] 
36. Aschner Y, Downey GP. Transforming Growth Factor- $\beta$ : Master Regulator of the Respiratory System in Health and Disease. Am J Respir Cell Mol Biol. 2016; 54:647-655. [PubMed: 26796672]

37. Gore B, Izikki M, Mercier O, et al. Key role of the endothelial TGF- $\beta$ /ALK1/endoglin signaling pathway in humans and rodents pulmonary hypertension. PLoS One. 2014; 9:e100310. [PubMed: 24956016]

38. Roberts AB, Sporn MB. Regulation of endothelial cell growth, architecture, and matrix synthesis by TGF-beta. Am Rev Respir Dis. 1989; 140:1126-1128. [PubMed: 2679267]

39. Tørring PM, Brusgaard K, Ousager LB, et al. National mutation study among Danish patients with hereditary haemorrhagic telangiectasia. Clin Genet. 2014; 86:123-133. [PubMed: 24001356]

40. Gallione CJ, Richards JA, Letteboer TG, et al. SMAD4 mutations found in unselected HHT patients. J Med Genet. 2006; 43:793-797. [PubMed: 16613914]

41. Tillet E, Bailly S. Emerging roles of BMP9 and BMP10 in hereditary hemorrhagic telangiectasia. Front Genet. 2015; 5:456. [PubMed: 25620979]

42. Wooderchak-Donahue WL, McDonald J, O'Fallon B, et al. BMP9 mutations cause a vascularanomaly syndrome with phenotypic overlap with hereditary hemorrhagic telangiectasia. Am J Hum Genet. 2013; 93:530-537. [PubMed: 23972370]

43. Wang G, Fan R, Ji R, et al. Novel homozygous BMP9 nonsense mutation causes pulmonary arterial hypertension: a case report. BMC Pulm Med. 2016; 22(16): 17.

44. McDonald J, Wooderchak-Donahue W, VanSant Webb C, et al. Hereditary hemorrhagic telangiectasia: genetics and molecular diagnostics in a new era. Front Genet. 2015; 6:1. [PubMed: 25674101]

45. Harrison RE, Flanagan JA, Sankelo M, et al. Molecular and functional analysis identifies ALK-1 as the predominant cause of pulmonary hypertension related to hereditary haemorrhagic telangiectasia. J Med Genet. 2003; 40:865-871. [PubMed: 14684682]

46. Abdalla SA, Cymerman U, Rushlow D, et al. Novel mutations and polymorphisms in genes causing hereditary hemorrhagic telangiectasia. Hum Mutat. 2005; 25:320-321.

47. Prigoda NL, Savas S, Abdalla SA, et al. Hereditary haemorrhagic telangiectasia: mutation detection, test sensitivity and novel mutations. J Med Genet. 2006; 43:722-728. [PubMed: 16690726]

48. Trembath RC, Thomson JR, Machado RD, et al. Clinical and molecular genetic features of pulmonary hypertension in patients with hereditary hemorrhagic telangiectasia. $\mathrm{N}$ Engl $\mathrm{J}$ Med. 2001; 345:325-334. [PubMed: 11484689]

49. Greenwald J, Fischer WH, Vale WW, et al. Three-finger toxin fold for the extracellular ligandbinding domain of the type II activin receptor serine kinase. Nat Struct Biol. 1999; 6:18-22. [PubMed: 9886286]

50. Austin ED, Ma L, LeDuc C, et al. Whole Exome Sequencing to Identify a Novel Gene (Caveolin-1) Associated with Human Pulmonary Arterial Hypertension. Circ Cardiovasc Genet. 2012; 5:336-343. [PubMed: 22474227]

51. Quest AF, Leyton L, Párraga M. Caveolins, caveolae, and lipid rafts in cellular transport, signaling, and disease. Biochem Cell Biol. 2004; 82:129-144. [PubMed: 15052333]

52. Kim CA, Delépine M, Boutet E, et al. Association of a homozygous nonsense caveolin-1 mutation with Berardinelli-Seip congenital lipodystrophy. J Clin Endocrinol Metab. 2008; 93:1129-1134. [PubMed: 18211975]

53. Cao H, Alston L, Ruschman J, et al. Heterozygous CAV1 frameshift mutations (MIM 601047) in patients with atypical partial lipodystrophy and hypertriglyceridemia. Lipids Health Dis. 2008; 7:3. [PubMed: 18237401]

54. Schrauwen I, Szelinger S, Siniard AL, et al. A Frame-Shift Mutation in CAV1 Is Associated with a Severe Neonatal Progeroid and Lipodystrophy Syndrome. PLoS One. 2015; 10:e0131797. [PubMed: 26176221]

55. Garg A, Kircher M, Del Campo M, et al. Whole exome sequencing identifies de novo heterozygous CAV1 mutations associated with a novel neonatal onset lipodystrophy syndrome. Am J Med Genet A. 2015; 167A:1796-1806. [PubMed: 25898808] 
56. Drab M, Verkade P, Elger M, et al. Loss of caveolae, vascular dysfunction, and pulmonary defects in caveolin-1 gene-disrupted mice. Science. 2001; 293:2449-2452. [PubMed: 11498544]

57. Hartung A, Bitton-Worms K, Rechtman MM, et al. Different routes of bone morphogenic protein (BMP) receptor endocytosis influence BMP signaling. Mol Cell Biol. 2006; 26:7791-7805. [PubMed: 16923969]

58. Wertz JW, Bauer PM. Caveolin-1 regulates BMPRII localization and signaling in vascular smooth muscle cells. Biochem Biophys Res Commun. 2008; 375:557-561. [PubMed: 18725205]

59. Prewitt AR, Ghose S, Frump AL, et al. Heterozygous null bone morphogenetic protein receptor type 2 mutations promote SRC kinase-dependent caveolar trafficking defects and endothelial dysfunction in pulmonary arterial hypertension. J Biol Chem. 2015; 290:960-971. [PubMed: 25411245]

60. Ma L, Roman-Campos D, Austin ED, et al. A novel channelopathy in pulmonary arterial hypertension. N Engl J Med. 2013; 369:351-361. [PubMed: 23883380]

61. Ketchum KA, Joiner WJ, Sellers AJ, et al. A new family of outwardly rectifying potassium channel proteins with two pore domains in tandem. Nature. 1995; 376:690-695. [PubMed: 7651518]

62. Olschewski A. Targeting TASK-1 channels as a therapeutic approach. Adv Exp Med Biol. 2010; 661:459-473. [PubMed: 20204749]

63. Olschewski A, Li Y, Tang B, et al. Impact of TASK-1 in human pulmonary artery smooth muscle cells. Circ Res. 2006; 98:1072-1080. [PubMed: 16574908]

64. Gardener MJ, Johnson IT, Burnham MP, et al. Functional evidence of a role for two-pore domain potassium channels in rat mesenteric and pulmonary arteries. Br J Pharmacol. 2004; 142:192-202. [PubMed: 15066906]

65. Osipenko ON, Evans AM, Gurney AM. Regulation of the resting potential of rabbit pulmonary artery myocytes by a low threshold, O2-sensing potassium current. Br J Pharmacol. 1997; 120:1461-1470. [PubMed: 9113366]

66. Gurney AM, Osipenko ON, MacMillan D, et al. Two-pore domain K channel, TASK-1, in pulmonary artery smooth muscle cells. Circ Res. 2003; 93:957-964. [PubMed: 14551239]

67. Remillard CV, Tigno DD, Platoshyn O, et al. Function of Kv1.5 channels and genetic variations of KCNA5 in patients with idiopathic pulmonary arterial hypertension. Am J Physiol Cell Physiol. 2007; 292:C1837-C1853. [PubMed: 17267549]

68. Moudgil R, Michelakis ED, Archer SL. The role of k+ channels in determining pulmonary vascular tone, oxygen sensing, cell proliferation, and apoptosis: implications in hypoxic pulmonary vasoconstriction and pulmonary arterial hypertension. Microcirculation. 2006; 13:615632. [PubMed: 17085423]

69. Peacock AJ, Murphy NF, McMurray JJ, et al. An epidemiological study of pulmonary arterial hypertension. Eur Respir J. 2007; 30:104-109. [PubMed: 17360728]

70. Grünig E, Koehler R, Miltenberger-Miltenyi G, et al. Primary pulmonary hypertension in children may have a different genetic background than in adults. Pediatr Res. 2004; 56:571-578. [PubMed: 15295086]

71. Chida A, Shintani M, Yagi H, et al. Outcomes of childhood pulmonary arterial hypertension in BMPR2 and ALK1 mutation carriers. Am J Cardiol. 2012; 110:586-593. [PubMed: 22632830]

72. Pfarr N, Fischer C, Ehlken N, et al. Hemodynamic and genetic analysis in children with idiopathic, heritable, and congenital heart disease associated pulmonary arterial hypertension. Respir Res. 2013; 14:3. [PubMed: 23298310]

73. Arora R, Metzger RJ, Papaioannou VE. Multiple roles and interactions of Tbx4 and Tbx 5 in development of the respiratory system. PLoS Genet. 2012; 8:e1002866. [PubMed: 22876201]

74. Bongers EM, Duijf PH, van Beersum SE, et al. Mutations in the human TBX4 gene cause small patella syndrome. Am J Hum Genet. 2004; 74:1239-1248. [PubMed: 15106123]

75. Ballif BC, Theisen A, Rosenfeld JA, et al. Identification of a recurrent microdeletion at 17q23.1q23.2 flanked by segmental duplications associated with heart defects and limb abnormalities. Am J Hum Genet. 2010; 86:454-461. [PubMed: 20206336]

76. Nimmakayalu M, Major H, Sheffield V, et al. Microdeletion of 17q22q23.2 encompassing TBX2 and TBX4 in a patient with congenital microcephaly, thyroid duct cyst, sensorineural hearing loss, and pulmonary hypertension. Am J Med Genet A. 2011; 155A:418-423. [PubMed: 21271665] 
77. SzafranskiSzafranski P, Coban-Akdemir ZH, Rupps R, et al. Phenotypic expansion of TBX4 mutations to include acinar dysplasia of the lungs. Am J Med Genet A. 2016; 170:2440-2444. [PubMed: 27374786]

78. Fujiwara M, Yagi H, Matsuoka R, et al. Implications of mutations of activin receptor-like kinase 1 gene (ALK1) in addition to bone morphogenetic protein receptor II gene (BMPR2) in children with pulmonary arterial hypertension. Circ J. 2008; 72:127-133. [PubMed: 18159113]

79. Levy M, Eyries M, Szezepanski I, et al. Genetic analyses in a cohort of children with pulmonary hypertension. Eur Respir J. 2016; 48:1118-1126. [PubMed: 27587546]

80. Harrison RE, Berger R, Haworth SG, et al. Transforming growth factor-beta receptor mutations and pulmonary arterial hypertension in childhood. Circulation. 2005; 111:435-441. [PubMed: 15687131]

81. Chida A, Shintani M, Nakayama T, et al. Missense mutations of the BMPR1B (ALK6) gene in childhood idiopathic pulmonary arterial hypertension. Circ J. 2012; 76:1501-1508. [PubMed: 22374147]

82. Takeda M, Otsuka F, Nakamura K, et al. Characterization of the bone morphogenetic protein (BMP) system in human pulmonary arterial smooth muscle cells isolated from a sporadic case of primary pulmonary hypertension: roles of BMP type IB receptor (activin receptor-like kinase-6) in the mitotic action. Endocrinology. 2004; 145:4344-4354. [PubMed: 15192043]

83. Chida A, Shintani M, Matsushita Y, et al. Mutations of NOTCH3 in childhood pulmonary arterial hypertension. Mol Genet Genomic Med. 2014; 2:229-239. [PubMed: 24936512]

84. Rostama B, Peterson SM, Vary CP, et al. Notch signal integration in the vasculature during remodeling. Vascul Pharmacol. 2014; 63:97-104. [PubMed: 25464152]

85. Kennard S, Liu H, Lilly B. Transforming growth factor-beta (TGF- $\beta 1$ ) down-regulates Notch3 in fibroblasts to promote smooth muscle gene expression. J Biol Chem. 2008; 283:1324-1333. [PubMed: 17981798]

86. Pousada G, Baloira A, Valverde D. Complex inheritance in Pulmonary Arterial Hypertension patients with several mutations. Sci Rep. 2016; 6:33570. [PubMed: 27630060]

87. Cogan J, Austin E, Hedges L, et al. Role of BMPR2 alternative splicing in heritable pulmonary arterial hypertension penetrance. Circulation. 2012; 126:1907-1916. [PubMed: 22923426]

88. Souza R, Humbert M, Sztrymf B, et al. Pulmonary arterial hypertension associated with fenfluramine exposure: report of 109 cases. Eur Respir J. 2008; 31:343-348. [PubMed: 17959632]

89. Montani D, Achouh L, Dorfmüller P, et al. Pulmonary veno-occlusive disease: clinical, functional, radiologic, and hemodynamic characteristics and outcome of 24 cases confirmed by histology. Medicine (Baltimore). 2008; 87:220-233. [PubMed: 18626305]

90. Runo JR, Vnencak-Jones CL, Prince M, et al. Pulmonary veno-occlusive disease caused by an inherited mutation in bone morphogenetic protein receptor II. Am J Respir Crit Care Med. 2003; 167:889-894. [PubMed: 12446270]

91. Tew MB, Arnett FC, Reveille JD, et al. Mutations of bone morphogenetic protein receptor type II are not found in patients with pulmonary hypertension and underlying connective tissue diseases. Arthritis Rheum. 2002; 46:2829-2830. [PubMed: 12384956]

92. Nunes H, Humbert M, Sitbon O, et al. Prognostic factors for survival in human immunodeficiency virus-associated pulmonary arterial hypertension. Am J Respir Crit Care Med. 2003; 167:14331439. [PubMed: 12615632]

93. Greenwood RD, Nadas AS. The clinical course of cardiac disease in Down's syndrome. Pediatrics. 1976; 58:893-897. [PubMed: 136632]

94. Reviron-Rabec L, Girerd B, Seferian A, et al. Pulmonary complications of type 1 neurofibromatosis. Rev Mal Respir. 2016; 33:460-473. [PubMed: 26868668]

95. Lo SM, Liu J, Chen F, et al. Pulmonary vascular disease in Gaucher disease: clinical spectrum, determinants of phenotype and long-term outcomes of therapy. J Inherit Metab Dis. 2011; 34:643650. [PubMed: 21445609]

96. Alghamdi MH, Steinraths M, Panagiotopoulos C, et al. Primary pulmonary arterial hypertension and autoimmune polyendocrine syndrome in a pediatric patient. Pediatr Cardiol. 2010; 31:872874. [PubMed: 20411253] 
97. Kane GC, Sachdev A, Villarraga HR, et al. Impact of age on pulmonary artery systolic pressures at rest and with exercise. Echo Res Pract. 2016; 3(2):53-61. [PubMed: 27343212]

98. Pousada G, Baloira A, Valverde D. Methylation Analysis of the BMPR2 Gene Promoter Region in Patients With Pulmonary Arterial Hypertension. Arch Bronconeumol. 2016; 52:293-298. [PubMed: 26654628]

99. Keusch S, Hildenbrand FF, Bollmann T, et al. Tobacco smoke exposure in pulmonary arterial and thromboembolic pulmonary hypertension. Respiration. 2014; 88(1):38-45. [PubMed: 24853610]

100. Wilkins MR, Aldashev AA, Wharton J, et al. a1-A680T variant in GUCY1A3 as a candidate conferring protection from pulmonary hypertension among Kyrgyz highlanders. Circ Cardiovasc Genet. 2014; 7:920-929. [PubMed: 25373139]

101. Elliott CG, Glissmeyer EW, Havlena GT, et al. Relationship of BMPR2 mutations to vasoreactivity in pulmonary arterial hypertension. Circulation. 2006; 113:2509-2515. [PubMed: 16717148]

102. Girerd B, Montani D, Coulet F, et al. Clinical outcomes of pulmonary arterial hypertension in patients carrying an ACVRL1 (ALK1) mutation. Am J Respir Crit Care Med. 2010; 181:851861. [PubMed: 20056902]

103. Germain M, Eyries M, Montani D, et al. Genome-wide association analysis identifies a susceptibility locus for pulmonary arterial hypertension. Nat Genet. 2013; 45:518-521. [PubMed: 23502781]

104. Chung WK, Austin ED, Best DH, et al. When to offer genetic testing for pulmonary arterial hypertension. Can J Cardiol. 2015; 31:544-547. [PubMed: 25840103] 

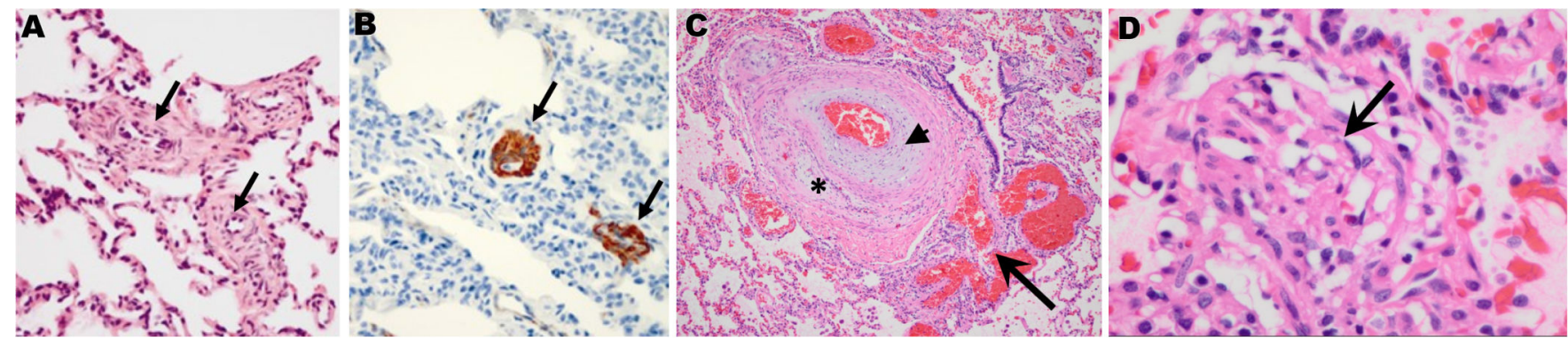

Figure 1.

Typical pathological features of PAH. A, B: Lung biopsy from a PAH patient with a $C A V 1$ mutation (grade I and II). H\&E staining shows medial thickening of small pulmonary arteries (Panel A, arrows), and pulmonary vascular smooth muscle cell proliferation -confirmed by immunohistochemical staining of alpha smooth muscle actin (Panel B, arrows) [51]. C, D: Lung tissue from a PAH patient with a $K C N K 3$ mutation. Panel $\mathrm{C}$ shows intimal proliferation, fibrosis (arrow head) and recanalization (asterisk), with an adjacent angiomatoid lesion (arrow) typical of pulmonary arterial hypertension (grade III). Grade IV disease includes plexiform lesions characterized by endothelial and intimal proliferation (Panel D, arrow) [61]. 


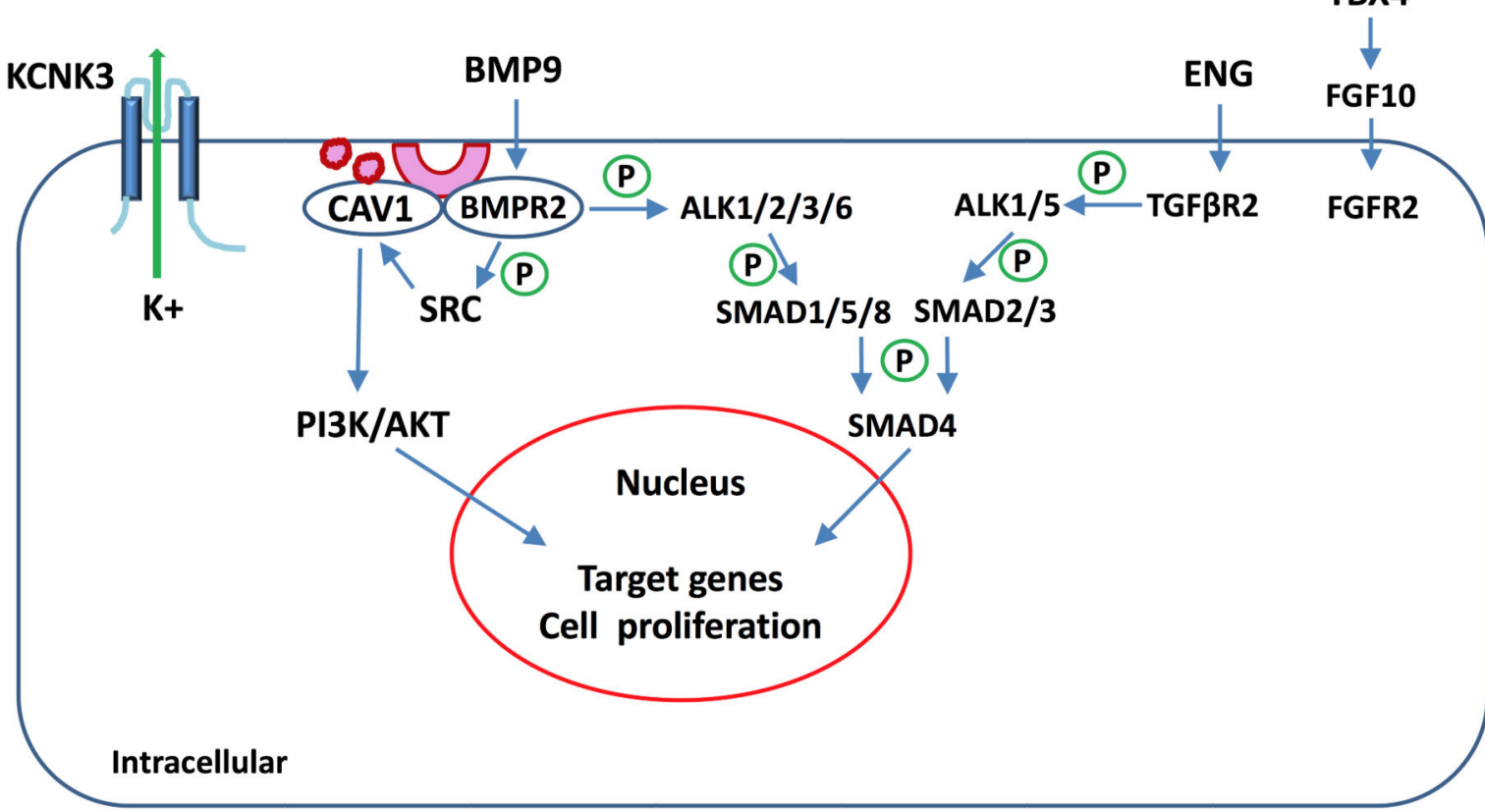

Extracellular

Figure 2.

PAH genes and signaling pathways. BMP ligands, such as BMP9, bind to BMPR2. Upon ligand binding, BMPR2 phosphorylates BMPR1, including ALK1, ALK2, ALK3 or ALK6 (ACVRL1, ACVR2, BMPR1A or BMPR1B respectively). The ligand-receptor complex phosphorylates SMAD1/5/8 and subsequently phosphorylates SMAD4. The phosphorylated SMADs translocate to the nucleus and regulate expression of target genes. TGF- $\beta$ ligands, such as ENG, bind TGF $\beta$ R2 to phosphorylate TGF $\beta$ RI, including ALK1 (ACVRL1) and ALK5 (TGFBR1). The complex phosphorylates SMAD2/3 which phosphorylates SMAD4 and translocates to the nucleus. CAV1 interacts with BMPR2 to prevent vascular proliferation. BMPR2 phosphorylates SRC, which regulates cell proliferation or regulates CAV1 to activate PI3K/AKT activity. KCNK3 encodes a 2-pore potassium channel and regulates membrane potential as well as vascular tone. TBX4 regulates fibroblast growth factor 10 (FGF10), which binds with fibroblast growth factor receptor 2 (FGFR2) to regulate development in lung. 


\section{Table 1}

Results of genetic studies in adult PAH.

\begin{tabular}{cccccc}
\hline Reference & Number of patients & BMPR2 & ACVRLI & ENG & TBX4 \\
\hline Deng Z, 2000 [11] & 35 & $7(20 \%)$ & & & \\
Humbert M, 2002 [13] & 33 & $3(9.1 \%)$ & & & \\
Morisaki H, 2004 [14] & 34 & $13(38.2 \%)$ & & & \\
Koehler R, 2004 [15] & 99 & $11(11.1 \%)$ & & & \\
Roberts KE, 2004 [16] & 40 & $3(7.5 \%)$ & & & \\
Rosenzweig EB, 2008 [17] & 69 & $15(21.7 \%)$ & & & \\
Sztrymf B, 2008 [12] & 223 & $68(30.5 \%)$ & & & \\
Wang H, 2010 [18] & 76 & $14(18.4 \%)$ & & & \\
Pfarr N, 2011 [19] & 231 & $49(21.2 \%)$ & $0(0 \%)$ & $0(0 \%)$ & \\
Kabata H, 2013 [20] & 49 & $18(36.7 \%)$ & & & \\
Kerstjens-Frederikse WS, 2013 [21] & 49 & & & & \\
Navas P, 2016 [22] & 165 & $19(11.5 \%)$ & & & \\
\hline Mutation frequency & & $220(20.9 \%)$ & $0(0 \%)$ & $0(0 \%)$ & $6(2.8 \%)$ \\
\hline
\end{tabular}




\section{Table 2}

Results of genetic studies in pediatric PAH.

\begin{tabular}{cccccc}
\hline Reference & Number of patients & BMPR2 & ACVRLI & ENG & TBX4 \\
\hline Grünig E, 2004 [70] & 13 & $0(0 \%)$ & & & \\
Roberts KE, 2004 [16] & 66 & $3(4.5 \%)$ & & & \\
Harrison RE et al., 2005 [80] & 18 & $2(11.1 \%)$ & $1(5.6 \%)$ & $1(5.6 \%)$ & \\
Rosenzweig EB, 2008 [17] & 78 & $8(10.3 \%)$ & & & \\
Fujiwara M, 2008 [78] & 21 & $4(19.0 \%)$ & $5(23.8 \%)$ & & \\
Chida A, 2012 [71] & 57 & $18(31.6 \%)$ & $7(12.3 \%)$ & & \\
Pfarr N, 2013 [72] & 40 & $6(15.0 \%)$ & $2(5.0 \%)$ & $2(5.0 \%)$ & \\
Kerstjens-Frederikse WS, 2013 [21] & 20 & & & & $6(30.0 \%)$ \\
Levy M, 2016 [79] & 66 & $5(7.5 \%)$ & $4(6.1 \%)$ & $0(0 \%)$ & $3(4.5 \%)$ \\
\hline Mutation frequency & & $46(12.8 \%)$ & $19(9.4 \%)$ & $3(2.4 \%)$ & $9(10.5 \%)$ \\
\hline
\end{tabular}

